\title{
Consumer decision-making models within the discipline of consumer science: a critical approach
}

\author{
Alet C Erasmus, Elizabeth Boshoff and GG Rousseau
}

\begin{abstract}
OPSOMMING
Verbruikersbesluitnemingsmodelle word algemeen in verbruikersgedragnavorsing gebruik om die navorsing te struktureer en te konseptualiseer. Verskeie van die tradisionele modelle - wat in die laat sestiger en sewentigerjare saamgestel is - is in handboeke beskikbaar wat terselfdertyd die teorie ter ondersteuning bied en die stappe van die verbruikersbesluitnemingsproses definieer en bespreek. Verbruikersbesluitneming word meestal in terme van vyf stadia voorgehou. Die modelle verskil grootliks ten opsigte van die klem en konteks sowel as detail wat ingesluit word.
\end{abstract}

In die tagtigerjare het navorsers begin besef dat die tradisionele modelle van verbruikersbesluitneming nie noodwendig die korrekte beeld van die verbruikersbesluitnemingsproses weergee nie, Verskeie navorsers het resultate van studies gepubliseer om aan te toon dat alternatiewe tot die tradisionele verbruikersbesluitnemingsmodelle gevind moes word. Feitlik sonder uitsondering toon besware ' $n$ oorbeklemtoning van eksterne en omgewingsfaktore op verbruikersbesluitneming sowel as ' $\mathrm{n}$ wanvoorstelling dat aktiewe beplanning en rasionele denke komplekse besluitneming rig. Verbruikersbesluitneming het oor jare baie meer kompleks geraak as gevolg van 'n groter verskeidenheid produkte wat beskikbaar is, ontwikkeling op die gebied van tegnologie, wêreldinvloede, groter bedingingsmag van werkende vroue wat ook op besluitnemingstrategieë in gesinsverband ' $n$ invloed het. Veralgemening van verbruikersbesluitnemingsprosesse in terme daarvan om tradisionele besluitnemingsmodelle te gebruik om bepaalde prosesse voor te stel, is nie meer haalbaar nie.

Die positivisme wat algemeen as perspektief vir die beskouiing van verbruikersbesluitneming beskou is (en nog steeds deur sommge beskou word) blyk nie al die moontlikhede te bied om die fenomeen te beskryf nie. Sterk steun vir die implimentering van subjektivistiese benadering en veral kwalitatiewe navorsingstegnieke in navorsing waar die verbruiker toegelaat word om gedagtes en idees spontaan te ontvou, word bepleit. In ooreenstemming met ' $n$ voorstel van Sheth (1981) word navorsers op die gebied van verbruikersgedrag in die verbruikerswetenskap gemotiveer om kreatief te dink binne minder rigiede teoretiese raamwerke sodat daar deur middel van navorsingsmetodes en tegnieke wat groter ruimte vir die ontdek van die onverwagte, meer omtrent verbruikergedrag aan die lig kan kom. Indien bestaande teorie van verbruikersgedrag gekombineer word met produkspesifieke (byvoorbeeld behuising, kleding, huishoudelike toerusting) teorie kan nuwe insigte bekom word wat waardevol en rigtinggewend kan wees in verbrui-

\section{INTRODUCTION}

Consumer behaviour $^{1}$ and consumer decision-making ${ }^{2}$ have become prominent research topics in the various fields of consumer science in recent years. Consumer science includes the former discipline of home economics and refers to a discipline that evolves around consumer behaviour and decision making concerning foods and nutrition, clothing and textiles, housing and interior merchandise in everyday living in order to meet basic and higher order needs for physical, psychological, socio-psychological and financial satisfaction in a complex micro and macro environment. Of specific importance is that buying and consumer decision-making are complicated as a result of external influences that have to be handled within an internal frame of reference that has come about through consumer socialization (that may be/have been restricted). Consumer behaviour within the discipline of consumer science focuses on consumption behaviour $^{3}$ where the humane aspect of decision making and purchasing is of major importance as opposed to buyer behaviour - the domain of the marketing and business professionals who wish to understand buyer behaviour (Schiffman \& Kanuk, 2000:5).

Consumer decision-making models are widely used in consumer behaviour research and study areas to structure theory and research. In a discussion of the consumer decision-making process, Engel, Blackwell \& Miniard (1995:143) state that "a model is nothing

\footnotetext{
${ }^{1}$ Consumer behaviour: those actions directly involved in obtaining, consuming, and disposing of products and services, including the decision processes that precede and follow these actions (Engel et al, 1995:G3)

${ }^{2}$ Consumer decision-making: the behaviour patterns of consumers, that precede, determine and follow on the decision process for the acquisition of need satisfying products, ideas or services (Du Plessis et al, 1991:11).

${ }^{3}$ Consumption behaviour: the style and process of consuming and possessing, collecting and disposing of consumer products and services including the resultant change of feelings, moods and attitudes toward the products and services (Schiffman \& Kanuk, 2000:G3).
}

\section{- Mrs AC Erasmus \\ - Prof E Boshoff \\ Department of Consumer Science \\ University of Pretoria, \\ - Prof GG Rousseau \\ Department of Industrial Psychology \\ University of Port Elizabeth}


more than a replica of the phenomena it is designed to present. It specifies the building blocks (variables) and the ways in which they are interrelated." Models are also described as flow charts of behavioural processes (Du Plessis, Rousseau \& Blem, 1991:18).

Advantages offered by models include the possibility to grasp visually what happens as variables and circumstances change, that models provide conceptual frames of reference that logically indicate the interrelationship of variables for research purposes, that models provide the possibility to understand different consumer decision processes and marketing strategies and that models play an important part in the establishment of theory (Engel et al, 1995:143; Du Plessis et al, 1991:18). Walters (1978:43) even proclaimed consumer decision-making models to "specify exact cause and effect that relate to consumer behaviour".

\section{TRADITIONAL MODELS OF CONSUMER DECISION-MAKING}

\section{Background}

Some of the best-known consumer decision-making models were developed in the 1960's and 1970's during a time characterized by limited theory on consumer behaviour and when theories from other disciplines were used. Until then, marketers rather than academics undertook research. This was all part of a developing discipline of consumer behaviour. Howard developed the first consumer decision-model in 1963 (Du Plessis et al, 1991:10). Others include the Nicosia-model (1966), Howard - Sheth- (1969), Engel, Kollat \& Blackwell- (1968), Andreason- (1965), Hansen(1972) and Markin-models (1968/1974). A concern was that consumer behaviour research did not grow from a pure theoretical basis and it is within this context that several theoretical models of consumer decision-making were developed (Du Plessis et al, 1991:9). These models, labelled the "grand models" of consumer decision-making (Kassarjian, 1982:20), tend to portray the process of proceeding through a major purchase decision ${ }^{4}$ as a logical problem solving approach (Cherian \& Harris, 1990:747). Furthermore, consumer decision-making is depicted as multi-staged and complex with several factors triggering problem recognition before initiating a sequence of actions to reach an outcome of satisfaction or dissatisfaction (Harrel, 1990:740; Cox, Granbois \& Summers, 1983:394). Differences between models lie primarily in their emphasis on particular variables and the manner of presentation (Du Plessis et al, 1991:32; Walters, 1978:42). The popularity of model building seemed to decrease after 1978 - especially in the case of comprehensive models (Van der Walt in Du Plessis et al, 1991:39). The consumer decision-

\footnotetext{
${ }^{4}$ Purchase decision: the process of weighing the consequences of product alternatives to come to a final product decision.
}

models that are still used today thus reflect the consumer decision process in terms of the interrelationship of concepts and flow of activities as understood within the limited theoretical background that inspired model building at the time.

Most of the consumer behaviour textbooks used as sources of consumer behaviour models for study and research purposes, refer to the elements (Cox et al, 1983:394; Harrel, 1990:740) of the consumer decision process in terms of the traditional five step classification, i.e. the cognitive decision sequence of problem recognition / pre-search stage, information search, alternative evaluation, choice, outcome evaluation (Schiffman \& Kanuk, 1994:566-580; Solomon, 1996:268; Du Plessis et al, 1991:27; Foxall, 1983:75). Some prefer to add one or more additional stages to place importance on certain phenomena/activities such as the inclusion of blocking mechanisms, the disposal of the unconsumed product or its remains (Du Plessis \& Rousseau, 1999:83; Engel et al, 1995:142, 143; Du Plessis, et al, 1991:38).

The classification in terms of various stages of consumer decision-making is typical of the rational approach to consumer decision-making (Punj \& Srinivasan, 1992:493-495; D'Astous, Bensouda \& Guindon, 1989:433). A rational approach to consumer decision-making refers to the careful weighing and evaluation of utilization or functional product attributes to arrive at a satisfactory decision (Solomon, 1996:268; Engel et al, 1995:G12). Rational goals are based on economic or objective criteria such as price, size and/ or capacity (Schiffman \& Kanuk, 2000:G11).

Engel et al (1995:4), in their discussion of "what consumer behavior is all about," identify the dominant research perspective in consumer behaviour as logical positivism. Positivism implies a research approach in which rigorous empirical techniques are used to discover generalized explanations and laws (Engel et al, 1995:G11). It is within this perspective that the "grand models" of consumer decision-making have been produced. When traditional models were later revised (1982 Engel, Kollat \& Blackwell-model, versus the 1978 model), more emphasis was placed on cognitive aspects of buying behaviour than before. These were called the contemporary models, but although they include aspects of mental activity, it is still difficult to ascertain whether these models are accurate and whether they have predictive value (Du Plessis et al, 1991:18, 19).

\section{CONSUMER DECISION-MAKING MODELS CRITICIZED}

Objections against the indiscriminate use of consumer decision-making models have been voiced since their introduction. Apart from the limited theoretical background within which traditional consumer decisionmaking models were developed and revised, the different forms of criticism can broadly be categorized in terms of: an assumption of rational consumer deci- 
sion-making behaviour; a generalization of the decision-making process; concern about the detail included in consumer decision-making models as well as limitations as a result of a positivistic approach to the development of consumer decision-making models.

\section{Rational consumer decision-making criticized}

In the 1980's, theorists began to question the rational approach to consumer decision-making because studies showed that for many products, consumers spend very little time or do not even engage in some of the sequential activities suggested as being important during consumer-decision making. It was found (as discussed by Bozinoff, 1982:481 based on work by Lachman et al, 1979) that consumers are frequently engaged in non-conscious behaviour during consumer decision-making. This implies that consumer decision models in fact attempt to explain highly subconscious matter in a consciously-oriented information paradigm.

Actual consumer decision-making processes might also, in some cases, appear to be haphazard and disorderly when in fact, they are functional and highly adaptive, although opportunistic (Hayes-Roth, 1982: 132). An opportunistic approach does not coincide with structured and rigid traditional decision-making models. Some researchers concluded that many consumers undertake little or no prepurchase informationsearch and undertake limited planning prior to entering retail stores (Solomon, 1996:269; D' Astous et al, 1989:433). It became clear that consumers possess and implement a repertoire of consumer decisionmaking strategies depending on the product, situation, context and previous experience (Solomon, 1996: 269). Some researchers even added that consumers do not typically apply analytical decision rules to optimize decisions but relied on heuristics that would lead to satisfying decisions instead (e.g. an "acceptable" price or "trusted" brand name) (Solomon, 1996:287).

The so-called "rational" consumer became the subject for several critical analyses which postulated that consumers engage in both cognitive and emotional information processing prior to a purchase (Schiffman \& Kanuk, 2000:461; Zajonc \& Markus in Lofman, 1991:729; D' Astous et al, 1989:433). Cognitive information processing refers to active, effortful planning and goal directed consumer behaviour that involves meditated intellectual activity, while emotional processing refers to the evaluation of product alternatives within more abstract parameters.

Ratchford and Vaughn (1989:298) suggested that ego gratification, social acceptance as well as sensory desires might imply different decision-making activities to those traditionally accepted and reflected in consumer decision-making models. Their concern was that one could easily, from the design of traditional consumer decision-making models, overemphasize the role and importance of external factors during consumer decision-making while neglecting or minimizing emotional aspects.
Bettman (1993:8) accentuates that an understanding of consumers' decision-making behaviour not only has to focus on what products do (functional and performance attributes), but also has to consider what products mean to consumers. Driven by emotional needs/ concerns, consumers are limited in the options they are willing to consider during the decision-making process and consequently adapt the decision-making strategy (Schiffman \& Kanuk, 2000:461; Bettman, 1993:8).

Schiffman and Kanuk (2000:439, 440) describe a rational consumer decision as one where the consumer is aware of all the product alternatives, where the consumer has the capability to correctly rank product alternatives in terms of benefits and disadvantages and is able to identify the best alternative. Arguments against rational consumer behaviour include the fact that consumers operate in an imperfect world, that they possess limited knowledge and skills and that certain values might dominate their goals and decisions. Rational consumer behaviour thus seems too idealistic and simplistic.

\section{A generalization of the consumer decision-making process}

Consumer decision-making models provide broad, organized structures that reflect the basic process of consumer decision-making from certain viewpoints and within certain contexts (Walters, 1978:42). These models are often used to structure and interpret consumer behaviour research - even for product specific research. This inevitably means that the research approach, when implementing a specific decision-making model, has to coincide with certain assumptions made by the original authors. Generalizing the decisionmaking process to such an extent for any consumer product might imply a biased view of, and approach to, the consumer decision-making process right from the start (Burns \& Gentry, 1990:522).

Sirgy (1983:16-18), studying the progress of consumer behaviour research within the theory of social cognition, criticized the traditional interpretation of consumer behaviour and proposed a level of analysis dimension: classifying some consumer decision processes at a microlevel (e.g. based purely on sensation, perception) some at the micro-macrolevel (including the five steps of decision-making, namely problem recognition, information search, alternative evaluation, outcome evaluation) and others at a macrolevel (referring to repeat purchase behaviour and diffusion of innovation). Sirgy suggested a categorization of consumer decisions for discussion and research purposes rather than a generalization of the decisionmaking process over the spectrum.

D' Astous et al (1989:433, 434) carried on with the work of Hoyer (1984) who concluded that consumer decision-making should be viewed considering the relevant dimensions of a purchase, i.e. frequency of purchase and importance of the purchase. Although it is not a hard-and-fast rule, it is generally accepted that 
the more important a product, the more complex the decision-making process, for example, when higher social, personal and financial risks are implicated, consumers usually engage in external information search and a more deliberative decision process (Du Plessis \& Rousseau, 1999:94-94; Du Plessis et al, 1991:27; Assael, 1989:31, 534). Consumers therefore devote more cognitive effort to the purchase of a product that is considered to be important.

Consumer decision-making models are also criticized as being somewhat idealized (Cox et al, 1983:394). Because extraordinary short planning periods for the purchasing of complex products are reported in some instances, a need for research to bring about a closer fit between theory and practice is suggested. Consumer decision-making models - due to their complexity and the detail included - give the impression that extended buying behaviour is the norm.

Within the constructivist framework it is argued that consumer attitudes and preferences - based upon previous experiences - are not revealed, but elicited during decision-making. Consumer goals are often imprecise - especially in situations of less frequent purchases - and are in fact constructed in a given situation within the boundaries of personal experiences. The assumption made in hierarchical models of consumer decision-making, namely that the decision to choose is independent of which alternative to choose, and that the decision-making process necessarily proceeds through the various stages to come to a final decision, may not always be valid. Consumers often decide to choose or not to choose depending on the existing situation (Dhar, 1992:735-737). This implies a more definite impact of in store search activities during consumer decision-making rather than preparedness before entering the store. Traditional consumer decision-making models do not portray this possibility clearly.

Traditional models of consumer decision-making assume that the decision-making process occurs in a serial or sequential fashion (Martin \& Kiecker, 1990:443). The English logician Alan Turing introduced the first of these in 1936. The basic assumption of most of these serial processing models, as delineated by Newell and Simon's theory of problem solving, requires that only one information process occurs at a time (Martin \& Kiecker, 1990:443). New models in the field of cognitive science depict information processing in a more parallel way to make provision for the fact that some stages of the decision-making process occur simultaneously. All traditional consumer decision-making models are of serial nature and since model building has declined after 1978 (Van der Walt, 1978 in Du Plessis et al, 1991:39), one may well wonder whether further research in this regard should not be pursued.

In a commentary on new theoretical perspectives in consumer behaviour, Stewart (1990:751-753) argues that although a lot has been done in the field of consumer decision-making, the focus has only been on a narrow range of phenomena. He proposes a simple model of consumer decision-making and emphasizes that a general assumption, namely that the end point of the consumer decision is the purchase, may be overly simplistic. He provides an alternative model with no obvious beginning or ending. Stewart recommends studies where the starting point of the decision-making process is deliberately changed (for example confronting consumers with different situations, such as entering the store) and to explore what actually happens before and after that specific situation. $\mathrm{He}$ further states that consumers often do not know the reasons for their actions and behaviour because decisions become automated. He concludes by stating that much has still to be learnt about consumer decision-making.

Comments on the detail included in consumer decision-models

Olshavsky and Granbois (1979:93) are of the opinion that "the most pervasive and influential assumption in consumer behavior research is that purchases are preceded by a decision process". These consumer behaviouralists asserted that information processing was often performed with previously acquired and stored information. This implies that consumers probably proceed through the decision-making process much quicker than is suggested/proposed by traditional consumer decision-making models (John \& Whitney, 1982:75). Some researchers are therefore of the opinion that consumer decision-making models often complicate a situation that is fairly straightforward. This argument supports the fact that consumer decision-making models tend to generalize conditions that are specialized, product and situation specific. Although the Engel Blackwell-model that was designed in 1982 (after the original Engel, Kollat \& Blackwell-model of 1968) (Du Plessis et al, 1991:25) approaches decision-making in terms of high and low involvement, it still seems very detailed and complex. Little has changed since the introduction of these models in the early years to accommodate the forementioned arguments.

Srinivasan's view (1993:290) seems to contradict the previous arguments when he states that consumers may, in the course of the decision-making process, be educated and inspired to upgrade their decisionmaking behaviour through implementing extensive information search. Unfortunately too much and too difficult information - due to an information overload often has the opposite effect. The information may then be rejected because it becomes a threat to a consumer's self-concept and confidence. The generation of information could also be very time-consuming and information search might even have financial implications. Consumers might find it less threatening, easier, quicker and cheaper to rely/draw upon a prior information base. In Srinivasan's view, even extensive product search might not always be as elaborate as is suggested in traditional consumer decision models. 
Consumers' choice processes vary according to the type of product involved, the timing and the people involved (Burns \& Gentry, 1990:520). No one consumer decision-making model could fully reflect all purchase decisions or all complex consumer decisions. Using consumer decision-making models to discuss or interpret consumer decision-making in general, is therefore an oversimplification of the true situation. Although Walters (1978:42) emphasizes that consumer decision-making models are an oversimplification of the reality, traditional consumer decision-making models - as a result of the detail included - might still be perceived as complex and elaborate to the inexperienced researcher and might give the impression that they have been designed to accommodate most aspects of decision-making.

Other concerns mentioned by Harrel (1990:739, 740), is that the multi-attribute models so frequently used to study and explain consumer decision-making, are founded on the assumption that attributes are important and that many of these models have a strong or even overemphasis on brand choice (e.g. the Howard Sheth-model as well as the Engel, Kollat \& Blackwellmodel) (Sheth \& Garrett in Harrel, 1990:739). Although brand decision-making represents a fair amount of deliberation during consumer decisionmaking, it does not represent the whole consumer decision-making process (Harrel, 1990:739).

\section{Presumed decision-making strategies}

In real world situations consumers are often faced with incomplete information and in most consumer decision situations, explicit, well-defined probabilities rarely exist and/or are difficult to formulate. This makes elaborate, rational decision-making as suggested by traditional consumer decision-making models almost impossible (Burke, 1990:250). Under such less than ideal conditions, decision shortcuts become the alternative. It is also suggested that even under ideal conditions, consumers actually "gamble" product alternatives as if they are forming statistical expectations based on probability-weighted outcomes of gambles which imply the use of a compensatory choice process. Much of the descriptive research on how consumers make decisions under uncertainty shows that consumers are highly concerned with negative information or losses. Consumers seem to think in terms of losses and gains relative to some neutral point and presume that losses tend to be stronger than gains. As a result, consumers eventually opt for the alternative with the smallest potential loss. This is a non-compensatory strategy that only focuses on losses and might be ascribed to consumers' inability to consider concepts/features of importance that would result in a satisfactory outcome (Hansen, 1992:175). Such decision-making behaviour deviates from the route of rational decision-making and cannot be described within a traditional consumer decisionmaking model.

Sharing the same views as Chhabra and Olshavsky (1986:12) who reported that alternative choice rules have been uncovered by researchers and that the evaluation of products is done holistically, based on preferences retrieved from memory, Burke (1990:250) recognizes the possibility of the use of alternative decision-making strategies (to those suggested in detailed consumer decision-making models) in situations where consumers are confronted with a lack of information. According to Burke, "missing information" forces consumers to opt for an alternative approach to consumer decision-making. This is probable in the case of complex decision-making that requires higher levels of understanding (as would be the case with technologically complex products) and where products are purchased less frequently so that consumers lack the relevant experience to proceed through the decision-making process as is portrayed in traditional models. When confused or overwhelmed, consumers tend to take alternative decision-making routes (Burke, 1990:251; Solomon, 1996:297).

In Chhabra and Olshavsky's opinion (1986:12), a consumer's retrieval of experience from memory strongly refers to so-called scripts and previous experience in decision-making activities. It is further proposed that consumers can even "decide not to decide", thus subcontracting a choice to another person such as the spouse. Alternatively, hybrid strategies could be used where consumers combine personal information with recommendations from sources such as friends. All these possibilities are difficult to detect from consumer decision-making models.

Bettman (1993:8) states that two major goals of decision-makers are to make a good decision and to conserve cognitive effort. Consumers generally trade-off the accuracy a given strategy might attain in a particular choice environment and the cognitive efforts required and as a result choose a strategy that represents a reasonable accuracy/effort trade-off for that task. This is a constructive view of choice where individuals change their processing to exploit what they have learnt (Bettman, 1993:8). Consumers use different decision-making strategies in different situations and this is not reflected in traditional consumer decision-making models.

Logical positivism used as theoretical approach to develop traditional consumer decision-making models Traditional models of consumer decision-making predominantly reflect the philosophy of classical economics (with the emphasis on ways and mechanisms to influence consumers) with evidence that the economic rationale has been enriched with especially psychological rationales (especially in the contemporary decision-making models) (Du Plessis et al, 1991:5; Firat, 1985:3). The theoretical approach, however, remains one of logical positivism.

In consumer decision-making models, predictions of consumer behaviour to help business best exploit and gain from trends in these behaviours, gain precedence over the understanding and explanation of consumer decision behaviour. Traditional models reflect a technological-managerial orientation with the em- 
phasis on influencing, controlling and managing certain phenomena (Firat, 1985:4). From the way these models have been developed, they have little concern about why certain actions occur despite a proclamation in this regard (as reported in Engel et al, 1995:143; Walters, 1978:42).

Both the disciplines of marketing and consumer behaviour have tended to investigate buyer behaviour rather than consumption behaviour. Apart from the fact that a study of buyer behaviour is of particular importance in business and marketing, a study of buyer behaviour requires more easily applicable and comprehensible measurements and scales. Engel, Kollat and Blackwell as well as Nicosia have admitted this (Firat, 1985:5). A study of consumption behaviour on the other hand may contribute to suggestions for better satisfaction of consumer needs - an aspect that is of major concern to consumer scientists, while buyer behaviour is more conducive to a marketing approach.

\section{Concluding remark}

Almost two decades ago Firat (1985:5) pointed out that traditional consumer decision-making models and theories were developed within certain contexts, time frames and social situations. He explicitly warned that when the same models were applied in other contexts and with other product categories, they become forced and cause imbalances. Although consumer behaviour theory has since grown considerably, the popularity of model building has decreased after 1978 (Du Plessis et al, 1991:39) - almost as if the initial efforts are generally being accepted as "acceptable / the ultimate/ flawless". Continued research is proposed to address concerns to eventually gain an improved understanding of the consumer decision-making process. Within the discipline of consumer science, this would provide more focused guidelines for efforts aimed at educating, assisting and facilitating consumers.

\section{IMPLICATIONS OF CRITICISM FOR CONSUMER DECISION-MAKING RESEARCH}

\section{Introduction}

Coinciding with Sheth's proposals for future research within the discipline of consumer behaviour (Sheth, 1981:667), arguments in favour of a reconsideration of a rational approach to consumer decision-making have been summarized above. Consumer behaviour as a scientific discipline was originally closely tied to the marketing concept (Schiffman \& Kanuk, 2000:6; Du Plessis et al, 1991:4; Sirgy, 1983:8). Sheth's ideal - later supported by Olson (1982:v) as well as Harrel (1990:737) - was that researchers in the field of consumer behaviour should ultimately attempt to contribute to concept formation and theory within the discipline itself, rather than to blindly borrow from disciplines such as marketing or social psychology. They also proposed that researchers explore alternatives to the logical positivistic research paradigm so that other theories and conceptual frameworks could be used instead of reliance upon traditional consumer decision-making models. This is in contrast with the view of Engel et al (1995:4, G11) who still believe the dominant research perspective in consumer behaviour to be logical positivism.

Suggestions for research based on the criticism of traditional consumer decision-making models

\section{Reconsidering a rational approach to consumer} decision-making Many of the objections against traditional consumer decision-making models refer to the fact that consumers do not necessarily embark upon extensive, active, cognitive laden, realistic and goal directed decision-making behaviour when purchasing complex, high-risk consumer products (Lofman, 1991:729). Consumer decision-making models should be more representative of what happens in real life situations without building on preconceived assumptions of what happens during the decision-making process and what is (supposed to be) important. Rassuli and Harrel (1990:737) inter alia suggest allowance for non-rational consumer behaviour and warn against the assumption that product attributes (functional aspects) as well as external factors are considered important in the decision outcome.

Scripts (event schemata) as cognitive structures in memory that have been stored through experience, have been found to be used by individuals in situational context to automatically direct behaviour (at any stage) when activated (Sutherland, 1995:413; Stratton \& Hayes, 1993:173; Whitney \& John, 1983:662; Bozinoff, 1982:481). The particular usefulness of a script is that a consumer primarily wants to conserve effort in buying behaviour and a script enables an individual to act in stead of relearning the steps of appropriate buying behaviour with every purchase (Martin, 1991: 225). Turning to consumers who have experienced purchasing situations and have them share their experiences as well as including qualitative research techniques to prompt them to recall their decision-making activities might provide valuable information on consumer decision-making within the context of consumer science. Such an approach will simultaneously conform to proposals made by researchers such as Bettman $(1993: 7,8)$, Lofman (1991:729), D'Astous et al (1989:433-435, 436), Bozinoff (1982:481), Sheth (1981:667-668), and others.

\section{Context and product specific consumer decisions} Rather than generalizing complex consumer decisionmaking, it is suggested that a study of consumer decision-making behaviour should be context specific and product specific to provide new insights and to contribute to theory building in the domain of consumer science. As early as 1956 , Koch concluded that consumer behaviour might either be extrinsically or intrinsically motivated and that the objective usefulness of a product only partially explains a specific purchase (Lofman, 1991:729). Ahtola (1984) and Hirschman \& Holbrook (1982) (in Lofman, 1991:730; Hudson \& Murray, 1986:34) emphasized that emotional desire 
often overrides utilitarian motives even for highly functional commodities such as household appliances.

Scripts as an alternative to consumer decision models have certain structural characteristics that offer potential in this regard (Puto, 1985:404).

Simplifying consumer decision-models Consumers often have to cope with complex, high-risk decisions that involve a sizable outlay of money, within a short period of time and without extensive information seeking. Traditional decision-making models imply the opposite (Ozanne, 1988:574). It is therefore suggested that a subjectivist approach be used to focus on consumption behaviour rather than purchase- / decision-making- I buyer behaviour (Holbrook \& Hirschman, 1982 in Lofman, 1991:730) (Hudson \& Murray, 1986:345) in order to accommodate the influence of emotional and non-rational aspects on consumer behaviour.

One of the prominent characteristics of a script is that it contains only the generic details of an event and does not include details of an event (Whitney \& John, 1983:662; Abelson, 1981:723). This could result in concept formation and theory building specifically within the domain of consumer behaviour and consumer science while at the same time reducing the possibility of too much and irrelevant detail .

\begin{abstract}
Allowing for alternative decision-making strategies Traditional consumer decision-making models are based on the premise that for complex, high-risk products, extensive decision-making takes place. Various researchers have reported quite the opposite. Reasons given, inter alia, include situations where information is either incomplete (Burke, 1990: 250, 251) or confusing because it is irrelevant, too difficult, or there is too much information to interpret (Hansen, 1992:175). It has also been found that consumers follow alternative decision-making strategies to conserve cognitive effort (Bettman, 1993:8, 10). Chhabra and Olshavsky $(1986: 12-13,16)$ attributed this to preconceived scripts in memory that direct the decisionmaking experience, resulting in proceeding much faster through the decision-making process.
\end{abstract}

The suggestion that a script is elicited from memory when an individual is confronted with a specific decision-making experience and that the individual then reacts on previous experiences captured in memory, might provide more realistic avenues for describing consumer decision-making (Abelson, 1981:723).

Implementing an alternative theoretical approach A positivistic tradition presumes consumers to be passive entities who respond to the push and pull of past impressed forces and current situational stimuli $(S \rightarrow R$; $\mathrm{S} \rightarrow \mathrm{O} \rightarrow \mathrm{R})^{5}$ with a causal type of explanation for actions (Schiffman \& Kanuk, 2000:462). A positivistic approach does not allow for intentional action mediated by meaning, deliberation of consequences of

\footnotetext{
${ }^{5}$ S: stimulus; R: response; O: cognitive interpretation
}

various alternatives and formation of intentions (Du Plessis et al, 1991:21; O' Shaughnessy, 1985:305). Theorists began to question the assumption of the rational consumer in the early 1980's and postulated that consumers engage in both cognitive and emotional processing during consumer decision-making (Zajonk \& Markus, 1982 in Lofman, 1991:729). The revised Engel Kollat Blackwell-model is an example of an attempt to include this phenomenon (Du Plessis et al, 1991:25). The hedonic consumption paradigm was suggested as an alternative for the study of consumer behaviour. This is based on psychological theories and is more concerned with those aspects of consumption that relate to the multisensory images, fantasies and emotive aspects of product usage (Lofman, 1991:729).

Due to the abundance of work done on rational consumer decision-making models, more research that acknowledges behaviour that may have underlying cognitive structure is suggested (Sheth, 1981:667). Harrel (1990:737) confirms Sheth's proposals and suggests considering a subjectivist approach for consumer behaviour research: thus a change from logical positivism to humanism and recommending the use or incorporation of qualitative research techniques to allow for more than the obvious. Qualitative research methods and techniques allow for the true views of consumers to unfold and allow for the unexpected an important prerequisite for theory building and concept formation (Schiffman \& Kanuk, 2000:14, 15).

A subjectivist approach does not view the discovery of causal laws, but rather examines the meaning of human action with the goal of attaining understanding. From the subjectivist perspective, credible knowledge is generated through making anti-positivist and ideographic assumptions. The world is thus considered to be essentially perceptual and is understood or studied from the point of view of individuals who are directly involved in the activities which are to be studied (Burrell \& Morgan, 1979 in Hudson \& Murray, 1986:344)

An advantage of implementing a subjectivist approach is that there is no initial reduction of variables. Research techniques allow and encourage participants to spontaneously unfold their experiences and purchase-related behaviour and fantasies (Hudson \& Murray, 1986:345). Script elicitation procedures meet these recommendations.

\section{CONCLUSION}

Consumer behaviour as a discipline originated in the mid- to late 1960's. Many of the early theories were based on the economics theory presuming that consumers act rationally to maximize satisfaction in their purchase of goods and services (Schiffman \& Kanuk, 2000:6). The consumer decision models and theories developed in the early years are still being used to structure research in the field of consumer behaviour and consumer sciences despite evidence that con- 
sumer decision-making is a more complex phenomenon and that it can not be generalized over the wider spectrum of consumer goods.

Consumer facilitation, however, assumes an understanding of the consumer as a prerequisite. Researchers within the field of consumer science with an interest to contribute to the theory and understanding of consumer behaviour will have to focus on consumption behaviour that includes the intricacies of emotions, situational factors as well as personal influences under specific circumstances rather than buyer behaviour per se. Although widely published and used, traditional models of consumer behaviour should not be regarded the norm for organizing research and the interpretation of research findings. An exploratory approach with the intention to unfold the "truth" might provide exciting, inspiring opportunities for the understanding of the complexity of specific decision making circumstances such as first-time home purchasing, purchasing of household appliances, regular food purchasing activities, personal and family clothing selection.

The potential of scripts to "provide behavioral guidance" (Searleman \& Herrmann, 1994:126; Stoltman, Tapp \& Lapidus, 1989:385; Weisberg, 1980:56) and to reflect on the interaction of individuals and information in decision-making (Taylor, Cronin \& Hansen, 1991:17) seems promising. Unfortunately, since the introduction of scripts within the area of consumer behaviour in the late 1970's, and the first script elicitation studies done by Whitney and John (shopping script, 1983) and Stoltman and co workers (examination of shopping scripts in 1989) within this area, little has been done to extend and implement the script concept in practice. Consumer decision-making and relating theory provide exciting opportunities for future research by professionals in the consumer science discipline. Adding to what has been done in the field of marketing sciences, consumer scientists could contribute their product specific knowledge and experience towards a more holistic understanding of consumer behaviour to ultimately contribute to theory building to the benefit of all.

\section{REFERENCE LIST}

ABELSON, RP. 1981. Psychological status of the script concept. American Psychologist 36 (7): 715-729.

ASSAEL, H. 1989. Consumer behavior and marketing action. 3 rd ed. Boston. Kent.

BETTMAN, JR. 1993. The decision maker who came in from the cold. Advances in Consumer Research X: 7-11. Twenty third Annual Conference. [sl]. Association for Consumer Research.

BOZINOFF, L. 1982. A script theoretic approach to information processing: an energy conservation application. $A d$ vances in Consumer Research IX: 481-486. Twelfth Annual Conference. Missouri. Association for Consumer Research. BURKE, SJ. 1990. The effects of missing information on decision strategy selection. Advances in Consumer Research XVII: 250-256. Seventeenth Annual Conference. New Orleans. Association for Consumer Research.

BURNS, AC \& GENTRY, JW. 1990. Toward improving household consumption behavior research: avoidance of pitfalls in using alternative household data collection procedures. Advances in Consumer Research XVII: 518-523. Seventeenth Annual Conference. New Orleans. Association for Consumer Research

CHERIAN, J \& HARRIS, B. 1990. Capricious consumption and the social brain theory: why consumers seem purposive even in the absence of purpose. Advances in Consumer Research XVII:745-749. Seventeenth Annual Conference. New Orleans. Association for Consumer Research. CHHABRA, S \& OLSHAVSKY, RW. 1986. Some evidence for additional types of choice strategies. Advances in Consumer Research XIII:12- 17. Sixteenth Annual Conference. Missouri. Association for Consumer Research.

COX, A, GRANBOIS, DH \& SUMMERS, J. 1983. Planning, search, certainty and satisfaction among durables buyers: a longitudinal study. Advances in Consumer Research X:394399. Thirteenth Annual Conference. San Francisco. Association for Consumer Research.

D'ASTOUS, A, BENSOUDA, I \& GUINDON, J. 1989. A reexamination of consumer decision-making for a repeat purchase product: variations in product importance and purchase frequency. Advances in Consumer Research XVI:433438. Nineteenth Annual Conference. [sl]. Association for Consumer Research.

DHAR, R. 1992. To choose or not to choose: this is the question. Advances in Consumer Research XIX:735-738. Twenty second Annual Conference. [sI]. Association for Consumer Research.

DU PLESSIS, PJ \& ROUSSEAU, GG. 1999. Buyer behaviour. A multi cultural approach. Halfway House. International Thomson. Sigma.

DU PLESSIS, PJ \& ROUSSEAU, GG \& BLEM, NH. 1991. Consumer behaviour. A South African perspective. Pretoria. Sigma.

ENGEL, JF, BLACKWELL, RD \& MINIARD, PW. 1995. Consumer behavior. International ed. Florida. Dryden. FIRAT, AF. 1985. A critique of the orientations in theory development in consumer behavior: suggestions for the future. Advances in Consumer Research XXII:3-6. Fifteenth Annual Conference. New Orleans. Association for Consumer Research.

FOXALL, GR. 1983. Consumer choice. London. MacMillan.

HANSEN, DE. 1992. Issues in consumer choice with uncertain product outcomes. Advances in Consumer Research XIX:175 - 176. Twenty Second Annual Conference. [sl]. Association for Consumer Research.

HARREL, GD. 1990. A new perspective on choice. Advances in Consumer Research XVII:737- 745. Twentieth Annual Conference. New Orleans. Association for Consumer Research.

HAYES - ROTH, B. 1982. Opportunism in consumer research. Advances in Consumer Research IX:132-135. Twelfth Annual Conference. Missouri. Association for Consumer Research.

HUDSON, LA \& MURRAY, JB. 1986. Methodological limitations of the hedonic consumption paradigm and possible alternative: a subjectivist approach. Advances in Consumer Research XIII:343-348. Sixteenth Annual Conference. Missouri. Association for Consumer Research.

JOHN, G \& WHITNEY, JC. 1982. An empirical investigation of the serial nature of scripts. Advances in Consumer Research I X:75-79. Twelfth Annual Conference. Missouri. Association for Consumer Research.

KASSARJIAN, HH 1982. The development of consumer behavior theory. Advances in Consumer Research IX:20-22. Twelfth Annual Conference. San Francisco. Association for Consumer Research.

LOFMAN, B. 1991. Elements of experiential consumption: an exploratory study. Advances in Consumer Research XVIII:729 - 735. Twenty First Annual Conference. New Or- 
leans. Association for Consumer Research.

MARTIN, D \& KIECKER, P. 1990. Parallel processing models of consumer information processing: their impact on consumer research methods. Advances in Consumer Research XVII:443-448. Twentieth Annual Conference. New Orleans. Association for Consumer Research.

MARTIN, I. 1991. Expert novice differences in complaint scripts. Advances in Consumer Research XVIII:225-231. Twenty first Annual Conference. Association for Consumer Research.

OLSHAVSKY, RW \& GRANBOIS, DH. 1979. Consumer decision-making - fact or fiction. Journal of Consumer Research (6):93-100.

OLSON, JC. 1982. Presidential address: toward a science of consumer behavior. Advances in Consumer Research IX: $v-x$. Twelfth Annual Conference. San Francisco. Association for Consumer Research.

OZANNE, JL. 1988. Keyword recognition: A new methodology for the study of information seeking behaviour. $A d$ vances in Consumer Research XV:574- 579. Eighteenth Annual Conference. [sl]. Association for Consumer Research.

PUNJ, G \& SRINIVASAN, N. 1992. Influence of problem recognition on search and other decision process variables: a framework for analysis. Advances in Consumer Research XIX:491-497. Twenty Second Annual Conference. [sI]. Association for Consumer Research.

PUTO, CP. 1985. Memory for scripts in advertisements. Advances in Consumer Research XI1:404-409. Fifteenth Annual Conference. [sl]. Association for Consumer Research.

RASSULI, KM \& HARREL, GD. 1990. A new perspective on choice. Advances in Consumer Research XVII:737-744. Twentieth Annual Conference. [sl]. Association for Consumer Research.

RATCHFORD, BT \& VAUGHN, R. 1989. On the relationship between motives and purchase decisions: some empirical approaches. Advances in Consumer Research XVI:293299. Nineteenth Annual Conference. [sl]. Association for Consumer Research.

SCHIFFMAN, LG \& KANUK, LL. 1994. Consumer behavior. $5^{\text {th }}$ ed. London. Prentice Hall.

SCHIFFMAN, LG \& KANUK, LL. 2000. Consumer behavior. $7^{\text {th }}$ ed. London. Prentice Hall.

SEARLEMAN, A \& HERRMANN, D. 1994. Memory from a broader perspective. New York. McGraw Hill.

SHETH, JN. 1981. Consumer behaviour: surpluses and short comings. Advances in Consumer Research IX:667678. Twelfth Annual Conference. Missouri. Association for Consumer Research. .

SIRGY, MJ. 1983. Social cognition and consumer behavior. New York. Praeger Scientific.

SOLOMON, MR. 1996. Consumer behavior. Buying, having and being. $3 \mathrm{rd}$ ed. London. Prentice Hall.

SRINIVASAN, N. 1993. Consumer judgments, decisions and framing dynamics: An informational viewpoint. $A d$ vances in Consumer Research XX: 288-290. Twenty Third Annual Conference. [sl]. Association for Consumer Research

STEWART, DW. 1990. A commentary on new theoretical perspectives on consumer behavior. Advances in Consumer Research XVII:750. Twentieth Annual Conference. New Orleans. Association for Consumer Research.

STOLTMAN, JJ, TAPP, SR \& LAPIDUS, RS. 1989. An examination of shopping scripts. Advances in Consumer Research XVI:384-391. Nineteenth Annual Conference. [sl]. Association for Consumer Research.

SUTHERLAND, S. 1995. The Macmillan dictionary of psychology. New York. Macmillan

TAYLOR, SA, CRONIN, JJ jr \& HANSEN, RS. 1991. Schema and script theory in channels research. Marketing theory and applications. American Marketing Association Winter's Conference (2):15-24. [sl].

WALTERS, CG. 1978. Consumer behavior. Theory and practice. Ontario. Richard D Irwin.

WEISBERG, RW. 1980. Memory, thought and behavior. New York. Oxford University Press.

WHITNEY, JC \& JOHN, G. 1983. An experimental investigation of intrusion errors in memory for script narratives. Advances in Consumer Research X:661-666. Thirteenth Annual Conference. San Francisco. Association for Consumer Research. 